\title{
«From wheel of fortune to wheel of misfortune: Financial crises, cycles and consumer predation »
}

\author{
$\underline{\text { Auteurs }}$ \\ Olivier Mesly, David W. Shanafelt, Nicolas Huck
}

Document de Travail $n^{\circ} 2020-35$

Juillet 2020

Bureau d'Économie

Théorique et Appliquée

BETA

www.beta-umr7522.fr

19beta_economics

Contact :

jaoulgrammare@beta-cnrs.unistra.fr 
3 Olivier Mesly ${ }^{\mathrm{a}}$

$4 \quad$ ICN School of Business, Nancy, France.

$5 \quad$ Email: olivier.mesly@icn-artem.com

7 David W. Shanafelt

8 Université de Lorraine, Université de Strasbourg, AgroParis Tech, Centre national de la 9 Recherche Scientifique (CNRS), L'Institut National de Recherche pour l'Agriculture, 10 l'Alimentation et l'Environnement (INRAE), Bureau d'Économie Théorique et Appliquée 11 (BETA), Nancy, France

12 E-mail: david.shanafelt@inra.fr

Nicolas Huck ${ }^{\mathrm{b}}$

ICN School of Business, Nancy, France

Email: nicholas.huck@icn-artem.com

${ }^{a}$ Professor Olivier Mesly is associate professor at ICN School of Business in Nancy and guest professor at University of Lorraine. He is a member of the Centre Européen de Recherche en Économie Financière et Gestion des Entreprises (CEREFIGE).

b Professor Huck is associate professor at ICN School of Business in Nancy. He is a 


\section{From wheel of fortune to wheel of misfortune: Financial crises, cycles and} consumer predation (1)

Abstract: Predator-prey dynamics are widely used in ecology but seldom utilized in economics and marketing, despite their ability to express financial market agents' behaviors when considered in combination with economic cycles and financial crises. This multidisciplinary paper presents a stylized framework of a market cycle that combines the notions of supply and demand and predator-prey interactions between buyers and sellers of housing mortgages. We illustrate our framework using data from the Global Financial Crisis and a Lotka-Volterra predator-prey model. We find that with our framework we are able to capture the dynamics of the market, particularly the peak and decline in the number of sellers and sold subprime mortgages. Our framework sheds a new light on consumer behaviors, pinpointing how they can put themselves into vulnerable prey positions. This paper is one of the first of its kind to propose market phases and predator-prey dynamics nested in economic cycles and consumer buying trends. 45

Keywords: Toxic products; predator-prey behavior; financial crisis; regulations; 7 consumer abuse 8

JEL: M31, N22, N42, O16, P46, R31 0 1 
Financial markets have always contained idiosyncrasies (Brunnermeier and Sannikov, 2014), in which winners are few and losers are numerous (Sorescu et al., 2018; Kindleberger, 1996). Markets worldwide are poisoned by dysfunctionality (Aguilera and Vadera, 2008), with yet unexplored forms of social psychopathy (Boddy, 2015) and moral hazard, defined as, "the failure of either to behave diligently or in good faith at any point in the exchange" (Ericson and Doyle, 2003, p. 11).

The 2007-2009 Global Financial Crisis (GFC) is no exception. It arose due to a number of factors involving human decisions by both consumers and lenders (Glaeser, Gyourko and Saiz, 2008), hidden maneuvering and "unruly deregulation" (Krugman, 2009) such as the Glass-Stegall Act revision in the 1990's, which encouraged banks to seek unqualified clients (White, 2009) ${ }^{1}$.

Many experts blame quicksand-like regulations and excessively easy credit access (Fostel and Geanakoplos, 2012; West and Prendergast, 2009). Heavily misleading advertising and promotions were also factors that contributed to the mayhem (Ben-David, 2011; Calomiris and Wallison, 2008). Indeed, much of the unexplained volatility of the housing market can be explained by analyzing the interplay between astute, calculating financiers (predators) and naïve and overconfident buyers (prey) (Cochrane, 2005), which caused the extraordinary rise and equally spectacular collapse of housing prices. Many buyers dreamt of living exuberantly and thus exposed themselves to more risk than they should have (Shiller, 2005). Often buyers of subprime mortgages had little or no financial literacy (Dinwoodie, 2010), belonged to low income brackets (Roy and Kemme, 2012; Shiller, 2012), and suffered from cognitive and/or psychological weaknesses, making them more receptive to misleading advertising (Danis and Pennington-Cross, 2008; Wang, 2009; Yoon et al., 2005). As argued by some authors, the Federal Trade

\footnotetext{
${ }^{1}$ For a comprehensive review of the factors contributing to the GFC, see Acharya and Richardson (2009) and Razin and Rosefielde (2011).
} 
Commission failed to inform borrowers/consumers of the danger of subprime or predatory mortgages (Bone, 2008). ${ }^{2}$

The International Monetary Fund describes the rising home prices as a phenomenon that actually concealed the lax lending standards set by the U.S. government (IMF, 2009, Chap. 2). Originally, these standards were supposed to serve as barriers of entry into the market. But, in fact, they acted as an invitation for lenders to deceive and commit fraud, and created a pool of overstretched borrowers/consumers lured into the housing market by the temporary ease of financing or refinancing. Once these so-called "sweetheart deals" (including teaser rates) came due for renewal, consumers were faced with higher interest rates and monthly mortgage and credit card payments (Akerlof and Shiller, 2009; Ben-David, 2011). Then, as house prices plateaued or declined, those borrowers/consumers were doomed, facing delinquency or foreclosures. They no longer contemplated a wheel of fortune but rather a wheel of misfortune.

Our primary research question asks whether the incorporation of predator-prey dynamics into the depiction of the market can better explain the cyclical patterns of financial crises and, in particular, the GFC. To answer this question, we present a framework of a market cycle, incorporating predator-prey dynamics from ecology and notions of supply and demand. We discuss socio-psychological concepts inherent to consumer behavior that go beyond traditional assumptions such as rationality in economics, and the roles of human behavior in the GFC financial market. The present paper focuses on exceptional markets, specifically ones in which high levels of volatility and market frictions are nourished by toxicity in the form of predatory behavior between market agents. Indeed, it is a story of dysfunctional agents in dysfunctional markets.

In the context of predatory behavior in the mortgage industry, Hill and Kozup (2007) mention predatory lending as "consumer loans with any or all of the following

\footnotetext{
${ }^{2}$ By definition, a subprime mortgage is a type of adjustable-rate mortgage which, during an initial grace period, posses an interest rate below prime. However, as this grace period expires (usually after one year during the GFC), borrowers much renegotiate the mortgage to become either a fixed-rate or reviewed adjustable-rate mortgage. In general, post-grace period interest rates were at least at the prime rate, adjusted to take into account the risk of a borrower defaulting (Frame et al., 2008; IMF, 2009, Chap. 2).
} 
characteristics: aggressive and deceptive marketing, lack of concern for the borrower's ability to pay, high interest rates and excessive fees, unnecessary provisions that do not benefit the borrower... large prepayment penalties, or faulty underwriting...” (p. 29). They point to the fact that these predatory behaviors targeted vulnerable people who could easily fall for tricky contracts (p. 40) aimed at exploiting them through such measures as incomplete disclosure, inciting them to make "irrational choices" (p. 32). As another example, researchers have recognized that some lenders resorted to "predatory lending" - notably through misleading advertising (Gurun, Matvos, and Seru, 2016) and by soliciting unqualified borrowers ${ }^{3}$. Shiller (2005, p. 76) describes predatory lenders as follows: "When clever persons become professionals at deceiving people, and devote years to perfect their act, they can put seemingly impossible feats before our eyes and fool us, at least for a while." Yet the notion of adversarial relationships between lenders or providers of predatory mortgages and buyers has seldom been studied and merits, we believe, deeper study.

This is not to say that all sellers-buyers relationships were (or are) adversarial. Rather, we posit that a portion of the interactions between sellers and buyers during the dysfunctional market that was the U.S. during the GFC was plagued by adversarial relationships between lenders and providers of subprime or predatory mortgages, and some buyers. Our focus is on dysfunctional agents in dysfunctional markets. Normally, buyers and sellers engage in more of a symbiotic relationship, in which both parties benefit from the transaction. While there are always predatory interactions in the market, under most circumstances they do not threaten the stability of the system. However, when toxicity enters the market, the interaction between buyers and sellers can shift to be highly predatory in nature, where only a handful of market agents benefit at the expense of many. Millions of individuals suffered from the GFC, which saw massive foreclosures and delinquencies, reaching a value of USD 250 billion $^{4,5}$, representing $2 \%$ of U.S. GDP (Frame et al., 2008). All of the largest GFC market players in the U.S. were affected in the end, including Lehman Brothers, which closed, Bear Stearns and Merrill Lynch,

\footnotetext{
${ }^{3}$ Federal Trade Commission: https://www.ftc.gov/.

${ }^{4}$ U.S. Census Bureau, 2012: https://www.census.gov/.

${ }^{5}$ World Bank, 2013: http://donnees.banquemondiale.org/.
} 
which sought new owners, and Morgan Stanley and Goldman Sachs, which was transformed into bank-holding companies (BHCs).

In a similar vein, we do not wish to say that all consumers were gullible or engaged in improper behavior. Many were innocent bystanders caught in the wrong place at the wrong time, and suffered greatly as collateral damage. Similarly, we do not wish to claim that only the rich benefitted at the expense of the poor. Both poor and rich alike were hurt during the GFC, with the wealthy losing more in absolute value but the poor lost more as a percentage of total income (Frame et al., 2008). Instead, we focus on a subset of the market agents - whom engage in predatory behavior - that has a large impact on the market as a whole.

A more complete model than the ones currently used is warranted, one that accounts for the predatory interaction of lenders and borrowers/consumers and the cycling of the market as a whole. In this paper, we develop a framework of the housing market during the Global Financial Crisis. Our framework attempts to capture the functioning of the ailing financial market and, most notably, applies predator-prey theory from ecology to the dynamics between buyers and sellers of subprime (predatory) mortgages as nested in four cyclical phases (Q1 to Q4). We argue that the supply and demand associated with sellers and consumers of mortgages parallel the predator-prey dynamics between the buyers and sellers of subprime mortgages. We believe that these two approaches - normally treated separately - are, in fact, linked. Recognizing their relationship is a necessary advancement. Our approach proposes four phases within each economic cycle that can be seen as a consumer life cycle of its own: we posit that populations (aggregates) of consumers go through specific phases that imply different and at times harmful levels of vulnerability.

Our framework is grounded in three fields of study: predatory-prey models, disequilibrium models (economic phases), and Schumpter's theory of waves (market cycles). Decades ago, economists applied predatory mechanisms and Lotka-Volterra (LV) equations to financial market systems (Goodwin, 1967; Samuelson, 1971; Crookes 
and Blignaut, 2016). Currently, efforts are being made to explain economic phenomena using LV equations (Henry, 2012; Zhang, 2012; Dejuán and Dejuán-Bitriá, 2016; Ditzen, 2018), but rarely treat aggregates and flows as a dynamical system (Ryoo and Skott, 2008). To our knowledge, no such attempt has been convincingly made in marketing theory. Disequilibrium models address the transient nature of the market. They have furthered our understanding of how economic phases change over time and assisted in subduing the housing market discrimination that plagued the U.S. economy before the passage of the Fair Housing Act of 1968, but much of their focus has been on employment (Maddala, 1984). As for the phases of financial markets, most of their applications are concerned with growth, employment and productivity (Blanchard and Fisher, 1989). We know of no study that links them to Lotka-Volterra, predator-prey dynamics inherent to subprime-infected housing markets. In that vein, Schumpeter's theory of long waves, unemployment, and creative destruction can be summarized by the rise and fall of technology wavelets generated by population dynamics (Schumpeter $1934,1939,1950)^{6}$. It touches on the idea that aggregates are important in business cycle theory (Chen, 2005; Lucas 1981), but it falls short of predator-prey dynamics.

An alternative viewpoint is to consider financial crises as the result of random, historical events that appear in response to the interplay between credit financing and capital assimilation (Kotz, 2009). Marxism and neoliberalism offer two such perspectives. While Marxism emphasizes the elevation of the working class, neoliberalism - at least in the way it is practiced in the US - promotes contrasting actions, including deregulation (which gives more power to the most powerful people), reduction is social net spending (which disfavors the poorest), a shift in labor structure focusing on short-term contracts (thus making the vulnerable work force more vulnerable), and creditbased consumption versus sound capital building (Kotz, 2009). In these circumstances, the class gap that exists between the rich, the poor, and those attempting to get rich(er), can only widen. This perspective shows that what prevails in times of financial crisis is

\footnotetext{
${ }^{6}$ As well explained by Aghion, Akcigit, and Howitt (2013) in the context of growth processes, Schumpeter models, "... shed light on several aspects of the growth process which could not be properly addressed by alternative theories (...) (i) the role of competition and market structure; (ii) firm dynamics; (iii) the relationship between growth and development with the notion of appropriate growth institutions; (iv) the emergence and impact of long-term technological waves." (p. 2).
} 
the accumulation of capital through production, circulation and distribution of value, and labor shifts by some banking agents from regular employment to accumulating intangible financial assets (such as Special Purpose Entities, or SPEs) built to hide risk, sometimes referred to as "fictitious capital" (Fine, 2014, p. 50). While this viewpoint has merit, it does not address market cycles and cannot fully account for the tenets we set in this paper.

This paper is organized as follows. In the next section, we motivate and develop our framework of the housing market and explain the phases of a full economic cycle as we see it. We outline how consumers can become prey in certain market conditions, particularly in market cycles where predator-prey dynamics prevail. We thereafter provide evidence of our framework via market data extracted from the GFC. We conclude by outlying the benefits of our approach and opportunities for future research. We raise issues with respect to better protecting consumers against potential financial predators and, at times, against themselves.

\section{A FRAMEWORK OF FINANCIAL PREDATION ON CONSUMERS AND ECONOMIC CYCLES}

Current theories of business cycles do not consider predator-prey dynamics as concepts of aggregates and flows of predators (sellers), prey (potential buyers), and control regulations, at least not in a combined, interlocking way. As a first step towards achieving this end, we combine traditional notions of supply and consumer demand with predator-prey dynamics between buyers and sellers of housing mortgages. We show that the two frameworks run parallel to each other to drive the movements of the market cycle. We argue that there are underlying Lotka-Volterra dynamics implicit to standard supply and demand curves and that the two concepts should be considered together. 


\subsection{A framework of predator-prey dynamics}

228

229

230

231

232

233

234

235

236

237

238

239

240

241

242

243

244

245

246

247

248

249

250

251

252

253

In our framework of the housing market cycle, we use a basic predator-prey model that considers two agents or aggregates: (1) the number of sellers of subprime mortgages (population of predators), and (2) the number of potential buyers of predatory mortgages (population of prey). The number of subprime or predatory mortgages sold - aggregates of toxic products, i.e., "eaten" prey - can be calculated as a result of the interaction between buyers and sellers.

In order to model the predatory interaction between sellers and buyers of subprime mortgages, we adopt a well-known Lotka-Volterra (LV) predator-prey model borrowed from ecology (Gotelli, 1995; Hanski, 1999). The model expresses mathematically how populations of two species, in our case a predator and its prey, change over time. The classic application of the Lotka-Volterra model is the study of lynx and hare populations in Canada (Elton and Nicholson, 1942). The basic model incorporates growth and death of the prey and predator species separately, and - more importantly - the interaction between the two species (i.e., the number of prey that are caught and eaten by the predator $)^{7}$.

In the context of human interactions, toxic markets witness the emergence of market predators and in their wake, market prey. As policy regulations become weaker, the opportunity for predation on the part of astute financiers increases. Market predators use the idea of the American dream to bait vulnerable people (Wyly et al., 2007). Customers fall for it to the extent that they are naïve, vulnerable, or prone to greed (Shrum et al., 2014). During the GFC, many consumers abused access to credit and bet on poor investment habits (e.g., lack of diversification) (Hoffmann, Krause, and Laubach, 2012), boosted their credit card spending (Elul et al., 2010), lowered their guard and

\footnotetext{
${ }^{7}$ Lotka-Volterra equations adopt one of several mutually exclusive interactions depending on the sign of the interaction coefficients for each species (Gotelli, 1995; Song and Thakor, 2010). The sign of the interaction term (positive, negative, or zero) tells how one species affects the other (beneficial, harmful, or no effect). The most common interactions are competitive (both negative), predatory (one negative, one positive), or mutualistic (both positive).
} 
accepted to be influenced by aggressive marketing messages (Ben-David, 2011), or opted to disregard the risk of a debt trap (Reavis, 2012).

We do not wish to claim that all financiers are predatory, nor that the nature of the interaction is one-directional. Indeed, a small fraction of the banking system is considered as "shadow" banking, and consumers can certainly act in a predatory manner to sellers (see, for example "predatory borrowing" (Bianco, 2008), most notably in the form of consumers submitting falsified financial statements). Rather, we focus on a small portion of the financial market that has a potentially large impact on the overall economy. By the end of the GFC, the entire system crashed and caused a tsunami of economic and financial ills that swallowed banks such as Lehman Brothers and consumed the savings of millions of American consumers (Frame et al., 2008).

We represent the toxic U.S. market of the GFC as the result of the interaction between sellers and buyers of subprime mortgages (predators and prey respectively), which obey Lotka-Volterra equations (Lotka, 1920, 1925; Volterra, 1926, 1931). Under a predatory interaction, the LV equations come in the form of:

$$
\begin{array}{ll}
\frac{d x}{d t}=r x-\alpha x y & \text { for prey } \\
\frac{d y}{d t}=\alpha \beta x y-v y & \text { for predators }
\end{array}
$$

where $d x / d t$ and $d y / d t$ are the changes in the aggregates of prey (potential house buyers) and predators (sellers of subprime mortgages) over time. The coefficients $r$ and $v$ represent the growth and death rates of the prey and predator. That is, $r$ is the rate at which new potential buyers enter the market; $v$ is the rate at which sellers leave the market. The parameter $\alpha$ is a measure of the probability of potential buyers purchasing a subprime mortgage, and implicitly includes the rate of contact between buyers and sellers, social characteristics such as greed, federal interest rates, and so forth. The parameter $\beta$ describes the rate at which sold mortgages entice new sellers to join the market. From the consumer's perspective, it is a proxy for the risk of purchasing a 
subprime mortgage. All else equal, the parameter $\beta$ is the marginal influx of new sellers entering the market following a sale (caught prey). We present a side-by-side comparison of these parameters in ecological and market contexts in Table 1.

287 Table 1. Side-by-side comparison of Lotka-Volterra parameters.

\begin{tabular}{|c|c|c|}
\hline Parameter & \multicolumn{2}{|c|}{ Interpretation } \\
\hline & Ecology & Marketing and finance \\
\hline$r$ & $\begin{array}{l}\text { prey intrinsic growth rate or birth } \\
\text { rate }\end{array}$ & $\begin{array}{l}\text { rate at which new buyers enter the } \\
\text { market }\end{array}$ \\
\hline$\alpha$ & $\begin{array}{l}\text { predation rate (how well a predator } \\
\text { finds and captures prey) }\end{array}$ & $\begin{array}{l}\text { probability of a buyer purchasing a } \\
\text { subprime mortgage from a seller }\end{array}$ \\
\hline$\beta$ & $\begin{array}{l}\text { conversion efficiency (how eaten } \\
\text { prey become new predators) }\end{array}$ & $\begin{array}{l}\text { rate at which sold mortgages } \\
\text { attract new sellers to the market }\end{array}$ \\
\hline$v$ & predator death rate or mortality rate & $\begin{array}{l}\text { rate at which sellers leave the } \\
\text { market }\end{array}$ \\
\hline
\end{tabular}

All four parameters $(r, \alpha, \beta$, and $v)$ can be calibrated from experimental and/or market data (Appendix A). An example of the dynamics of the system of equations in (1.1) is presented in Figure 2b. The system of equations in (1.1) expresses the most basic predator-prey model, which has been extended over the decades to include more complex growth and predator response functions, time-varying parameters, and time lags (among others) (Edelstein-Keshet, 2005) ${ }^{8}$.

Our framework assumes that sellers act as predators in the sense that they intend to abuse their customers - prey - to serve their own interests, causing them financial harm and catching them by surprise. The literature is rich with the idea that consumers may be abused by astute sellers, and can suffer financial harm sometimes due to their own doing (by, for example, presenting erroneous financial statements to bankers in order to get loans, which will eventually drive them into financial debt). For example, Kim et al. (2019) point to low-income homeowners who end up struggling to make ends meet after

\footnotetext{
${ }^{8}$ Of particular interest is the effect of time lags, or, put differently, hysteresis. Hysteresis is a situation whereby the consequences of an action persist even after the action has ended (Grjebine and Tripier, 2017), Hence, the present events depend on past, expired events. Following that logic, present crises may actually be influenced by past, extinct crises. Economic contagion, as seen during the GFC, would therefore be not only transversal (affecting present populations) but also longitudinal, having an effect in the future, even when its current phase has become extinct.
} 
buying houses they could not afford due to such unexpected charges as repairs. In their view, consumers are often overconfident and neglect to seek proper advice ${ }^{9}$. To make matters worse, approximately $60 \%$ of American households are known to not maintain a budget, thus positioning themselves at risk of market hazard (Warmath and Zimmerman, 2019). Similarly, however, these authors note that even financial literacy can fail to improve self-protecting financial behaviors. Part of the explanation, they contend, rests in the fact that consumers (would-be prey) are not able or willing to admit their own decision-making weaknesses and choose to rely on untrustworthy sources of information.

These deficiencies are amplified in the context of home buying and financial crises. Indeed, homes are one of the most important purchases in a consumer's lifetime and certainly are a crucial element of the modern North American financial ecosystem (Nicholson et al., 2019). For consumers, the latter authors note that the high-cost and time-consuming activity of searching for and deciphering proper and complex information acts as a deterrent to sound decision-making. In short, consumers opt for "rational ignorance" (p. 128). This, as well, has important implications. Even trained consumers are not exempt from causing themselves financial harm, so that governmentfunded training may be, at times, pointless. Yet, another concern with respect to policy making and government-funded training programs: if consumers choose not to learn, one cannot force them to.

Our proposed framework presents four phases (Q1, Q2, Q3, and Q4) that together

\subsection{Cycles and the consumer's wheel of misfortune}

${ }^{9}$ This has important regulatory consequences. Even if training programs are put in place by governments, targeted consumers may not choose to benefit from them because they feel they are "above" such training. Their overconfidence ultimately leads to their demise. 
the system moves through each stage smoothly. While there are predator-prey dynamics, they are low and do not threaten the overall stability of the market. When market frictions (e.g., bankruptcies, stock shortages) increase beyond control, however, the economic system collapses. These frictions, we posit, are the result of runaway predator-prey dynamics among market agents. In such a system, the normal economic cycle inflates then capsizes. Figure 1 illustrates the stylized wheel of misfortune, which will be illustrated with actual market data in the following section.

$$
==
$$

\section{INSERT FIGURE 1 ABOUT HERE}

$$
==
$$

We refer to the first phase of the market cycle as low-vigilance phase (Q1 going to Q2). This corresponds to years 2000 to 2003 of the GFC, in which the number of subprime mortgages was allowed to increase in the market as government regulations were weak or weakened by economic policies. Eager house buyers drifted to lenders' offices as the barriers to entry (the required credit rating and the access to money) played to their perceived advantage, thus turning themselves into potential prey. As these consumers grew excited by the prospect of easy and rapid wealth, their level of vigilance declined.

The second phase represents the predator-prey market phase (Q2). It corresponds to the years 2003 to 2006, where sellers and buyers engaged in mutual deceit in order to achieve their goals, with buyers not yet realizing the toxicity of the mortgages they contracted. Sellers realized that profits could be made by developing subprime mortgages, the full effect of which will only came later, once the teaser rate period was over. Sellers hid the present risks in opaque financial tools such as Collateralized Debt Obligations (CDOs) or redistributed them geographically as was done with the REPO 105 mechanism of the Lehman Brothers. Let loose by weak regulations, suppliers (predators) and buyers (prey) engaged in economic activity revolving around a single asset - houses - defying one of the principal strategies of sound investments: 
diversification. Indeed, this is what happened during the GFC when astute sellers and overoptimistic buyers flooded the market, causing house prices to soar contagiously.

The third phase, we call the forward-fleeing phase (Q3), which captures the saturation and ultimately the collapse of the market from 2006 to 2009. Initially, the forward-fleeing stage was proactive and geared toward accumulation of assets (through subprime mortgages and pools of mortgages) but then, once the market hit its optimal toxicity and the grace period of mortgages ended, the forward-fleeing was based on panic with efforts to unload toxic products.

The final phase is the stalled phase (Q4). It corresponds to the years 2009 to 2012 in which the U.S. government tried to subdue the crisis by installing new regulations to better protect consumers. This phase was initially characterized by a temporary paralysis of economic activity: regulations impeded the drive of well-intentioned financiers or entrepreneurs and each played a game of cat and mouse in order to stay afloat. This delayed the development of productive economic activity. This temporary paralysis was necessary, however. As exemplified during the GFC, the government had to bring the overheated market to a stop with such measures as the Paulson plan ${ }^{10}$. In that case, the net effect was deleterious at first, much as cancer treatments are first harsh on the body before being beneficial. Such effects included forcing companies into bankruptcies (e.g., Lehman Brothers) and increasing consumer interest rates.

\subsection{Supply and Demand curves and the economic cycle}

Figure 2 decomposes the wheel of misfortune into its constituent phases according to supply and consumer demand curves and predatory interactions between sellers and buyers of subprime mortgages. The demand curve is expressed as the interplay between government regulations $\left(Q_{\text {reg }}\right)$ and the number of potential buyers of mortgages $\left(Q_{\text {buyers }}\right)$.

\footnotetext{
${ }^{10}$ The Paulson Plan or "Emergency Economic Stabilization Act of 2008" was a USD 700 billion bank bailout designed to relieve the market of its idiosyncrasies developed during the GFC.
} 
400

401

402

403

404 405

406

407

408

409

410

411

412

413

414

415

416

417

Increased government regulations (interest rates, used as a proxy) disincentive the purchase of new mortgages. That is, the laxer the regulations, the more the number of potential buyers (or prey) increases. The supply curve reveals the interaction between the quantity of sold subprime mortgages $\left(Q_{\text {mortgages }}\right)$ and the number of sellers of those mortgages $\left(Q_{\text {sellers }}\right)$. Naturally, sellers (predators) offer subprime mortgages (toxic products) to potential buyers (prey): the more sellers, the more sold predatory mortgages. We assume linear relationships for the demand and supply curves for the sake of simplicity.

$$
===
$$

\section{INSERT FIGURE 2 ABOUT HERE}

$$
==
$$

As we move along the supply and demand curves and forward in time in the LotkaVolterra dynamics, we move from one phase of the market cycle to another. Federal interest rates are implicit in our system, shifting the supply and demand curves and are contained within the parameters of the predator-prey model. In our framework, the supply and demand curves and predator-prey dynamics are implicitly linked, which makes our framework quite different from existing economic models. It is this approach, we posit, that renders a better representation of the market (see the next section).

We assume that the main characteristics of low-vigilance Q1 phase during any financial crisis are as follows: regulators-prey interactions prevail; however, regulations, which are meant to protect prey, start becoming lax (laissez-faire being considered in our framework a necessary antecedent to financial crises). There are few predators but a large number of healthy potential prey, who display a reverse risk-aversion behavior (or put differently, speculation, which is at the heart of over-indebtedness - Dejuán and DejuánBitriá, 2016). Demand (supply) for mortgages is at its maximum (minimum), paralleling the number of predators and prey in the market. 
We assume that the main characteristics of the predator prey market $(\mathrm{Q} 2)$ phase during any financial crisis are as follows: predator-prey dynamics become more dominant, and the rate of increase in the aggregate number of sellers and sold mortgages increases. Predators see the opportunity to develop their poisons and traps, as regulations get weaker and do not protect prey anymore. This is the beginning of the financial crisis. Prey start foraging for easy credit and investment bargains, thus exposing themselves to risk (expressed by the presence and action of predators). It is possible that new buyers of houses may be more avid than the first entrants, as they have gained additional trust in the market in that thus far the market had proved rewarding. Thus, demand and supply decline and increase respectively, with the interactions between predators and prey.

We assume that the main characteristics of the forward-fleeing Q3 phase during any financial crisis are as follows: predators developed and marketed toxic products, which often contained a lag effect (not until later would the prey realize that they had been caught in a debt trap - Dejuán and Dejuán-Bitriá, 2016). Unaware of the real risk, which was hidden, excited prey had flocked the market under a contagion effect. Supply peaked along with the number of sold subprime mortgages, and demand and the number of potential buyers declined.

We assume that the main characteristics of the stalled Q4 phase during any financial crisis are as follows: regulations control toxic products, left-over prey still invade the crisis-market, and the economic "cure" starts having a positive effect of the market. The system falls into Walrasian equilibrium, a return to normalcy ${ }^{11}$. Theoretically, in a Q4 phase, the market is competitive without being predatory. Prices are flexible and there are many agents in the market, and produced goods are fully allocated. However, regulations will eventually become inefficient again and predators will innovate better risk-hiding products that tap into unexploited resources (Bhargava,

\footnotetext{
${ }^{11}$ A Walrasian equilibrium corresponds to the traditional concept in economics of equilibrium (especially in auction activities) where traders use flexible pricing to make the system efficient. As an individual trader's transactions cannot influence prices, it is the entire population of traders that counts (Gul and Stacchetti, 1999).
} 

1989), so that the system falls into a phase of low vigilance (Q1). Innovation signifies less stability, so that the market cycles yet again (Chen, 2014).

450

\section{Supply and demand}

As interest rates rise $\left(Q_{\text {reg }}\right)$, consumers are less likely to buy houses $\left(Q_{\text {buyers }}\right)$.

The more toxic products there are on the market $\left(Q_{\text {mortgages }}\right)$, the more sellers are motivated to sell them $\left(Q_{\text {sellers }}\right)$

The market cycle

Q1 to $Q 2$ : $\quad$ The transition occurs when there is first excess demand for predatory mortgages, followed by an increasing supply of them on the market

Sellers overflow the market with predatory mortgages (Q2), but as

$Q 2$ and $Q 3: \quad$ interest rates increase, buyers can no longer consume (Q3); in other words, the predators "ate" their prey

As panic kicks in, sellers are forced to retreat or go out of business

Q3 and Q4: (e.g., Lehman Brothers) and, with adapted regulations, consumers' general ability to pay improves and the system is in a Walrasian equilibrium, a return to normalcy (Q4)

Q4 to $Q 1^{*}$ : $\quad$ Eventually regulations become inefficient and sellers innovate better 
When the economy is relatively friction-free, the wheel (economic cycle) turns smoothly as market agents move from one state of the market cycle to another. It starts going awry when toxicity invades, thus becoming a wheel of misfortune. The wheel considers the endogenous link between supply and consumers demand and the resulting dynamics between market agents. Quantities of sellers and buyers of subprime mortgages adjust each other dynamically, taking into account the number of toxic products in the system and federal regulations. Supply and demand are implicitly considered in the LV type interactions between the market agents (and vice versa).

\section{EMPIRICAL ILLUSTRATION OF THE FRAMEWORK}

We illustrate our framework using empirical data taken from the GFC. We calibrate the parameters of the simple predator-prey model of equation (1.1) to the GFC data, and find that it captures much of the dynamics of the data, particularly the peak and decline in the number of sellers and quantity of sold subprime mortgages (Figure 3).

For the empirical data, we used proxies for the predator-prey relationship as well as for the regulations-toxic products relationship. For prey, we compiled the number of foreclosures, adjusting for the normal rate of foreclosures prior to the $\mathrm{GFC}^{12}$. This will be an underestimate of the number of potential buyers of subprime mortgages. For predators, we used the ratio of shadow and traditional banking liabilities (Hein, 2012). For regulations, we resorted to the Federal Reserve (Feds) percent interest rate, which is the Feds' efforts to regulate the market ${ }^{13}$. Lastly, for the toxic products, we use the share of subprime to total mortgages sold in the U.S. during the $\mathrm{GFC}^{14}$. Finally, we transformed the data and applied a smoothing function to harmonize the scales such that the data could be presented cleanly and concisely ${ }^{15}$.

\footnotetext{
${ }^{12}$ Realty Trac: https://www.realtytrac.com/.

${ }^{13}$ US Federal Reserve: https://www.federalreserve.gov/.

${ }^{14}$ Inside Mortgage Finance: https://www.insidemortgagefinance.com/.

${ }^{15}$ The transformed data is unitless. All data is available on the "Open Science Framework" (osf.io/3924r) and will be made public after acceptance.
} 
We calibrated the predator-prey model by choosing parameter values that minimize the sum of squared differences between the dynamics of the predator-prey model and the data (Hilborn and Mangel 1997). As the number of potential buyers are unknown, we focus on the number of sellers and sold predatory mortgages. The latter is a result of the interaction between predators and prey, e.g. "eaten" prey ${ }^{16}$. A detailed and step-by-step explanation of the calibration process can be found in Appendix A. In short, we simulate the system of equations in (1.1) over a broad range of parameter values $(r, \alpha, \beta$, and $v)$. For each simulation, we calculate the squared error (difference) between the data and their corresponding values in the simulations. The parameter values that result in the lowest total error are the calibrated, best-fit parameters. The calibrated or best-fit predator-prey model is meant to illustrate the framework and the likely presence of predator-prey dynamics in the empirical data.

We present the data and fitted predator-prey model in Figure 3. The market data show that during the initial phases of low interest rates, the number of sellers and sold subprime mortgages increased (Q1 and Q2). As the market saturated, the Federal Reserve intervened and increased interest rates, causing the number of sellers and sold mortgages to decrease (Q3 and Q4). There was a lag between the time subprime mortgages were contracted and the end of their one-to-two-year teaser rates in which homebuyers faced steep mortgage rates. Foreclosures followed.

Even with a simple predator-prey model we are able to capture many of the dynamics of the data, particularly the peak and decline in the number of sellers and sold subprime mortgages. We attribute this discrepancy to simplicities in the framework, such as constant parameter values or (un)observables not captured in a simple predator-prey model (e.g., human behavior, explicit government interventions, etc.). Nonetheless, we believe that the framework provides convincing evidence of the presence of predator-prey

\footnotetext{
${ }^{16}$ Recall that the model considers only two aggregates: predators and prey. Federal interest rates are taken implicitly in the choice of parameters. The true number of buyers of subprime mortgages is unknown. Therefore, we focus on the number of sold subprime mortgages or "eaten prey", which are the direct result of the interaction between sellers and potential buyers. Foreclosures would be a function of sold mortgages, being less than or equal to the number of sold subprime mortgages. However, since not all foreclosures were the result of predatory mortgages, they can also be seen as a lower bound to the number of potential buyers.
} 
522 dynamics in the GFC data. Though beyond the scope of this paper, further investigation 523 is warranted.

524

525

526

527

528

529

530

531

532

533

534

535

536

537

538

539

540

541

542

543

544

545

546

547

548

549

550

551

552

\section{CONCLUSION}

This paper brings forward a new dimension to current financial models aimed at explaining business cycles in times of crises. We believe our paper clarifies the roles supply and demand and how these interact with the key actors of the market, including avid and/or naïve consumers. Our framework proposes four market phases that depend on the dynamics of aggregates of market agents as they evolve over time. Our approach incorporates Lotka-Volterra equations to obtain a better comprehension of market interactions, turmoil, and the driving factors leading to crisis. The market phases emphasize the role that consumers play in the cycle. While they are relatively passive in low-vigilance (Q1) and stalled (Q4) phases, they are active in the predator-prey (Q2), where they are predated upon, and forward-fleeing (Q3), where they attempt to exit a treacherous market. Hence, consumers are considered vulnerable during much of the economic cycle, in part due to their own doing (e.g., low-vigilance Q1). As discussed, aggressive advertising and abrasive selling tactics compound to render consumers even more fragile and more prone to inadvertently fall into unsustainable debt. Since our framework posits that all supply and demand dynamics hide inherent LV dynamics, this means that consumers are necessarily subject to moral hazard, a statement that calls for proper regulation of the market. Such regulation could apply to include stronger protection of consumers' rights (e.g., the right to be properly informed), better training and educational programs, more punitive measures aimed at curbing deviant seller behaviors, and a better system of classification of consumer complaints to include predatory-like characterizations of sellers' behaviors. 
554 We point to specific consumer behaviors that take place in the context of an 555 economic cycle whereby supply and demand are intrinsically linked to predator-prey 556 (LV) dynamics. This has important repercussions in the field of consumer behaviors: 557 certain consumers need to be protected against seller-predators and against themselves, 558 because of their vulnerabilities and/or inability to cope with or to even realize they are 559 prey to a web of deceitful practices. The latter is something that is barely discussed in the 560 literature on financial crises. We trust it can therefore be of assistance in both research 561 and public policy by highlighting an important weakness in consumer behavior. 562 Certainly, governments should continue to use traditional tools - such as interest rates 563 to regulate the market. However, they should also take into account consumer behavior: 564 the fact that some consumers are overconfident, choose to be or are rationally limited, are 565 overwhelmed by complex terminology and financial concepts, seek inaccurate assistance 566 in helping them to make rational decisions, or have difficulty to compare adequately their 567 different options. All of this, of course, damages their ability to survive in the 568 dysfunctional predatory-prey portion of an economic cycle (Q2). This being said, training programs certainly can have positive impacts, as long as consumers are aware of them. Marketing them is of the essence.

While we are hesitant to generalize our framework of financial predation to all market crises, we find that it can represent data of the GFC in the U.S. We may be able to further illustrate what happened before, during and after the housing-market crisis if we extended the framework to take into account other processes such as hysteresis. Our 577 
Acharya, V., and Richardson, M. (2009). "Causes of the financial crisis”, Critical Review Vol. 21 Issue: 2-3, pp. 195-210.

Aguilera, R.V., and Vadera, A.K. (2008). "The dark side of authority: Antecedents, mechanisms, and outcomes of organizational corruption", Journal of Business Ethics Vol. 77 Issue: 4, pp. 431-449.

Aghion, P., Akcigit, U., and Howitt, P. (2013). What do we learn from Schumpeterian 589 growth theory? National Bureau of Economic Research (NBER) Working Paper $18824,1-44$.

592

593

Akerlof, G. A., and Shiller, R. J. (2009). Animal Spirits: How Human Psychology Drives the Economy, and Why It Matters for Global Capitalism. New Jersey: Princeton University Press.

595

596

597

598

599

600

Bhargava, S. C. (1989). "Lotka-Volterra equations and the mechanism of technological substitution.” Technological forecasting and social change 35(3), 19-326.

Ben-David, I. (2011). "Financial constraints and inflated home prices during the real estate boom", American Economic Journal: Applied Economics, pp. 55-87.

Bianco, K. (2008). "The subprime lending crisis: Causes and effects of the mortgage meltdown.” New York: Wolters Kluwer Law \& Business.

Blanchard, O., and Fisher, S. (1989). Lectures on economics. USA, Massachusetts: MIT Press.

601 Bloomberg: https://www.bloomberg.com/quicktake/subprime-lending

602 Boddy, C.R. (2015) "Organisational psychopaths: a ten-year update", Management 603 Decision, Vol. 53 Issue: 10, pp. 2407-2432.

604 Bone, P.F. (2008). "Toward a general model of consumer empowerment and welfare in 605 financial markets with an application to mortgage servicers", Journal of Consumer 606 Affairs 42, Issue 2, pp. 165-188.

607 Brunnermeier, M.K., and Sannikov, Y (2014). "A macroeconomic model with a financial 608 sector”, American Economic Review 104 Issue: 2, pp. 379-421.

610 the credit mess", Opinion, September 23, 2008. 
Chen P (2005) Evolutionary economic dynamics: persistent business cycles, disruptive technology, and the trade-off between stability and complexity. In: Dopfer K (ed) The evolutionary foundations of economics, chapter 15. Cambridge University Press, Cambridge, pp 472-505

Chen, P. (2014). Metabolic growth theory: market-share competition, learning uncertainty, and technology wavelets. Journal of Evolutionary Economics, 24:239262.

Cochrane, J.H. (2005). Asset Pricing, revised edition. NJ: Princeton. Princeton University Press.

Crookes, D., and Blignaut, J. (2016). "Predator-prey analysis using system dynamics: An application to the steel industry." South African Journal of Economic and Management Sciences 19(5), 733-746.

Danis, M. A. and Pennington-Cross, A. (2008). "The delinquency of subprime mortgages", Journal of Economics and Business Vol. 60 Issue: 1, pp. 67-90.

Dejuán, Ó., and Dejuán-Bitriá, D. (2016). A predator-prey model to explain cycles in financial-led economies. Review of Keynesian Economics. Accepted for publication.

Dinwoodie, J.T. (2010). Ignorance is not bliss: Financial illiteracy, the mortgage market collapse, and the global economic crisis. University of Miami Business Law Review $18,181-219$.

Ditzen, J. (2018) Cross-country convergence in a general Lotka-Volterra model. Spatial Economic Analysis 13(2), 191-211.

Edelstein-Keshet, L. (2005). Mathematical models in biology. New York: Society for Industrial and Applied Mathematics.

Elton, C., and Nicholson, M. (1942) The ten-year cycle in numbers of the lynx in Canada. Journal of Animal Ecology 11, 1942.

Elul, R., Souleles, N.S., Chomsisengphet, S., Glennon, D., and Hunt, R. (2010). What "triggers" mortgage default? American Economic Review 100(2), 490-494.

Ericson, R. V., and Doyle, A. (2003). "The moral risks of private justice: The case of insurance fraud. Risk and morality", Toronto: University of Toronto Press, Inc.

Federal Trade Commission: https://www.ftc.gov/. 
Fine, B. (2014). Financialization from a Marxist perspective. International Journal of Political Economy 42(4), 47-66.

Fostel, A., and Geanakoplos, J. (2012). "Trenching, CDS, and asset prices: How financial innovation can cause bubbles and crashes", American Economic Journal: Macroeconomics Vol. 4 Issue: 1, pp. 190-225.

Frame, S., Lehnert, A., and Prescott, N. (2008). A snapshot of mortgage conditions with an emphasis on subprime mortgage performance. Federal Reserve. http://www.federalreserveonline.org/pdf/mf_knowledge_snapshot-082708.pdf.

Glaeser, E.L., Gyourko, J., and Saiz, A. (2008). "Housing supply and housing bubbles", Journal of Urban Economics Vol. 64, pp. 198-217.

Goodwin, R. (1967). "A growth cycle," in Socialism, Capitalism and Economic Growth, edited by C. Feinstein (Cambridge University Press).

Grjebine, T., and Tripier, F. (2017). Finance, crises et croissance. Revue d'économie financière 3(127), 121-134.

Gul, F., and Stacchetti, E. (1999). Walrasian Equilibrium with Gross Substitutes. Journal of Economic Theory 87, 95-124.

Gurun, U.G., Matvos, G., and Seru, A. (2016). Advertising Expensive Mortgages. Journal of Finance 71(5), 2371-2416.

Hanski, I. (1999). Metapopulation ecology, Oxford: Oxford University Press.

Hein, E. (2012). The macroeconomics of finance-dominated capitalism and its critics. Cheltenham, UK: Edward Elgar.

Henry, J.F. (2012). The Veblenian predator and financial crises: Money, fraud, and a world of illusion. Journal of Economic Issues XLVI(4), 989-1006.

Hilborn, R. and Mangel, M. (1997). The ecological detective: Confronting models with data. Princeton, New Jersey: Princeton University Press.

Hill, R.P., and Kozup, J.C. (2007). Consumer experiences with predatory practices. The Journal of Consumer Affairs 41(1), 29-46.

Hoffmann, M., Krause, M.U., and Laubach, T. (2012). Trend growth expectations and U.S. house prices before and after the crisis. Journal of Economic Behavior and Organization 83(3), 394-409. 
International Monetary Fund (IMF) (2009). World Economic Outlook. Washington, DC, April. http://www.imf.org/external/pubs/ft/weo/2009/update.

Kim, K.T., Lee, J., and Hanna, S.D. (2019). "The effects of financial overconfidence on the mortgage delinquency of US Households". The Journal of Consumer Affairs. https://doi.org/10.1111/joca.12287.

Kindleberger, C. (1996). "Manias, panics, and crashes: A history of financial crises, 3rd ed.”, New York: Basic Books.

Kotz, D.M. (2009). The Financial and Economic Crisis of 2008: A Systemic Crisis of Neoliberal Capitalism. Review of Radical Political Economics 41(3), 305-317.

Krugman, P. (2009). "Reagan did it”, International Herald Tribune (June 2).

Labye, A. (2011). La crise financière actuelle : une application du modèle de Minsky ? Revue d'économie financière 2(102), 263 à 284.

Lotka, A.J. (1920). Analytical note on certain rhythmic relations in organic systems. Proceedings of the National Academy of Science. U.S.A. 6: 410-415: doi:10.1073/pnas.6.7.410. PMC 1084562.

Lotka, A.J. (1925). Elements of Physical Biology. Baltimore, USA: Williams and Wilkins.

Lucas Jr., R. E. (1981). Studies in business-cycle theory. MIT Press, Cambridge.

Maddala, G.S. (1984) "Estimation of the Disequilibrium Model with Noisy Indicators". Manuscript, University of Florida.

Magill, M.J.P. (1979). The origin of cyclical motion in dynamic economic models. Journal of Economic Dynamics and Control 1, 199-218.

Mesly, O., Chkir, I., and Racicot, F.-E., (2018). Predatory cells and puzzling financial crises: Are toxic products good for the financial markets? Economic Modelling 78, $11-31$.

Minsky, H. (1980). Capitalist Financial Processes and the Instability of Capitalism. Journal of Economic Issues 14(2), 505-523.

Nicholson, G., Skelton, R., and Tarr, J-A. (2019). "An exploratory study of regulatory failure in the Australian home mortgage market", The Journal of Consumer Affairs 53 Issue 1, pp. 126-166. 
Razin, A., and Rosefielde, S. (2011). "Currency and financial crises of the 1990s and 2000s.” Working Paper 16754, National Bureau of Economic Research.

Reavis, C. (2012) "The Global Financial Crisis of 2008: The Role of Greed, Fear, and Oligarchs”, MIT Sloan Management Review, March 16, 2012.

Roy, S. and Kemme, D.M. (2012). "Causes of banking crises: Deregulation, credit booms and asset bubbles, then and now", International Review of Economics and Finance Vol. 24, pp. 270-294.

Ryoo, S. and Skott, P. (2008). Financialisation in Kaleckian economics with and without labour constraints. European Journal of Economics and Economic Policies 5, 357386.

Samuelson, P. A. (1971). Generalized predator-prey oscillations in ecological and economic equilibrium, Proc. Nat. Acad. Sci. U. S. A. 68, 980-983.

Schumpeter, J.A. (1934). The theory of economic development. Harvard University Press, Cambridge.

Schumpeter, J.A. (1939). Business cycles, a theoretical, historical and statistical analysis of the capitalist process. McGraw-Hill, New York

Schumpeter, J.A. (1950). Capitalism, socialism and democracy, 3rd Ed. Harper, New York

Shiller, R.J. (2005). "Irrational exuberance”, New York: Crown Publishing Group, a division of Random House, Inc.

Shiller, R.J. (2012). “The subprime solution: How today's global financial crisis happened, and what to do about it", Princeton, New Jersey: Princeton University Press.

Shrum, L. J., Lowrey, T. M., Pandelaere, M., Ruvio, A. A., Gentina, E., Furchheim, P., Steinfield, L. (2014). Materialism: the good, the bad, and the ugly. Journal of Marketing Management 30 (17-18), 1858-1881.

Song, F., and Thakor, A.V. (2010). Financial system architecture and the co-evolution of banks and capital markets. The Economic Journal 120, 1021-1055.

Sorescu, A., Sorescu, S.M, Armstrong, W.J., and Devoldere, B. (2018). "Two centuries of innovations and stock market bubbles", Marketing Science Vol. 37 Issue: 4, p. 507. 
The Financial Inquiry Crisis Report (2011). https://www.gpo.gov/fdsys/pkg/GPOFCIC/pdf/GPO-FCIC.pdf.

United Nations Office on Drugs and Crime (UNODC): www.unodc.org.

Volterra, V. (1926). Variazioni e fluttuazioni del numero d'individui in specie animali conviventi. Memoria della Reale Accademia Nazionale dei Lincei 2, 31-113.

Volterra, V. (1931). Variations and fluctuations of the number of individuals in animal species living together. In Chapman, R. N., Animal Ecology, 409-448. New York, USA: McGraw-Hill.

Wang, A. (2009). “Interplay of investors' financial knowledge and risk taking”, Journal of Behavioral Finance Vol. 10 Issue: 4, pp. 204-213.

Warmath, D., and Zimmerman, D. (2019). "Financial literacy as more than knowledge: the development of a formative scale through the lens of bloom's domains of knowledge", The Journal of Consumer Affairs 53(4), pp. 1602-1629.

West, D., and Prendergast, G.P. (2009). "Advertising and promotions budgeting and the role of risk", European Journal of Marketing; Bradford Vol. 43 Issue: 11/12, pp. 1457-1476.

White, W. R. (2009). “Should monetary policy Lean or Clean?” Federal Reserve Bank of Dallas Globalization and Monetary Policy Institute Working Paper No. 3.

Wolfstetter, E. (1982). Fiscal policy and the classical growth cycle. Journal of Economics 42(4), 375-393.

World Bank World Bank, 2013:

http://donnees.banquemondiale.org/indicateur/NY.GDP.MKTP.KD.ZG.

Wyly, E.K., Atia, M., Lee, E., and Mendez, P. (2007). Race, Gender, and Statistical Representation: Predatory Mortgage Lending and the US Community Reinvestment Movement. Environment and Planning A, 39(9), 2139-2166.

Yoon, C., Laurent, G., Fung, H., Gonzalez, R., Gutchess, A., Hedden, T., and Skurnik, I. (2005). Cognition, persuasion and decision making in older consumers. Marketing Letters 16(3), 429-441.

Zhang, Y. (2012). Lotka-Volterra evolutionary model of China's incremental institutional reform. Applied Economics letters 19, 367-371. 
In order to calculate the best-fit parameters of the predator-prey model, we choose the parameter values that minimize the sum of squared differences between the predator770 prey model and the GFC data (Hilborn and Mangel 1997).

$$
==
$$

\section{INSERT FIGURE S1 ABOUT HERE}

$$
==
$$

Then we simulate the system of equations in (1.1) over a broad range of parameter values $(r, \alpha, \beta$, and $v)$ (Figure $\mathrm{S} 1 \mathrm{~b})$. For each simulation, we calculate the sum of squared differences between the data and the closest corresponding values of the theoretical model. In layman's terms, it is squared difference or error between a data point and the simulation, evaluated and summed over every observation in the data. 


$$
S S D=\sum_{n=1}^{39}\left(X_{n}-\frac{x_{n}}{s_{f}}\right)^{2}+\sum_{n=1}^{39}\left(Y_{n}-\frac{y_{n}}{s_{f}}\right)^{2}
$$

798

799 where $n=1,2, \ldots, 39$ are observations from the data (39 quarterly data points from 2003

800 to 2012), $X_{n}$ and $Y_{n}$ are the number of potential buyers and sellers of subprime mortgages 801 in the data at observation $n, x_{n}$ and $y_{n}$ are the corresponding numbers of potential buyers 802 and sellers from the simulation at observation $n$, and $s_{f}$ is the scaling factor (Figure S2).

803

804

805

806

807

808

809

810

811

812

813

814

815

816

817

818

819

820

$$
==
$$

\section{INSERT FIGURE S2 ABOUT HERE}

$==$ 


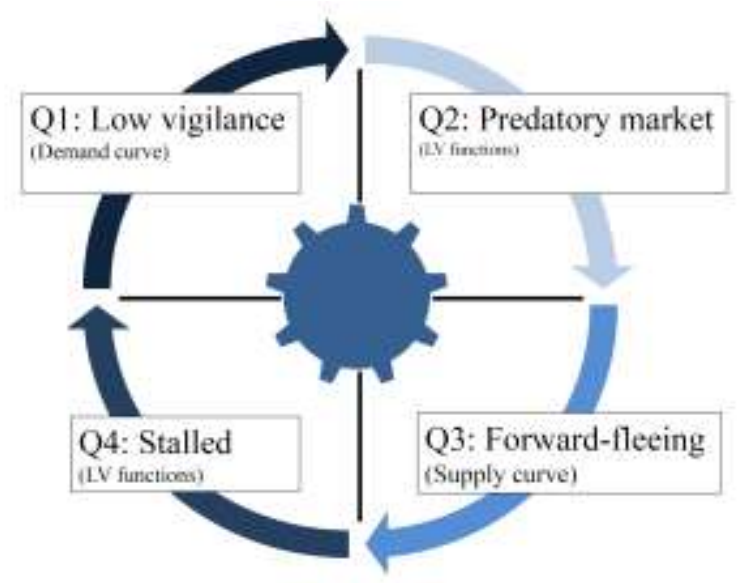

825

\section{Quadrant}

Q1

Q2

Q3

Q4
Phase

Low-vigilance

Predator-prey market

Forward-fleeing

Stalled
Time period in the GFC

2000 to 2003

2003 to 2006

2006 to 2009

2009 to 2012
827

828

829

830

831

832

833

Notes: When there are few regulations and vigilance is low (Q1), the market is bound to attract astute financiers. With possibilities of quick and easy profits emerging in the market, potential prey abound. Predators and prey engage in LV relationships (Q2). Toxic products - subprime mortgages - are developed as the result of the opportunistic interactions between predators and prey whereby the latter suffer at the hands of the former, which eventually leads to consumers' panic (Q3). Regulations set by regulators eventually adapt to the emergence of toxic products that cause market frictions (Q4). 
(a)

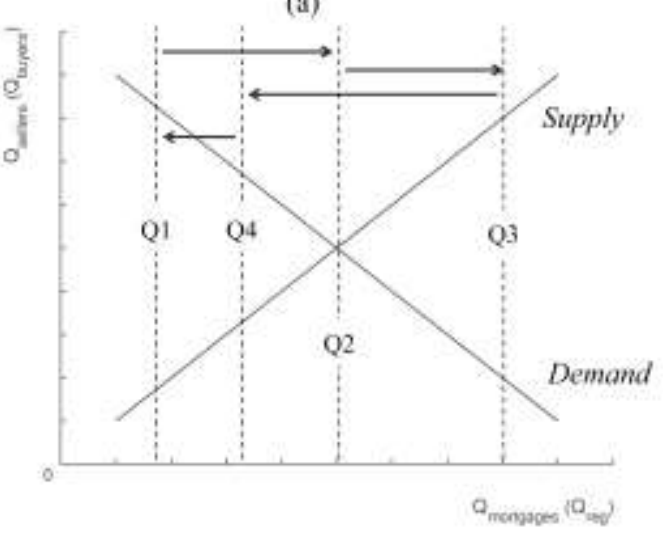

(b)

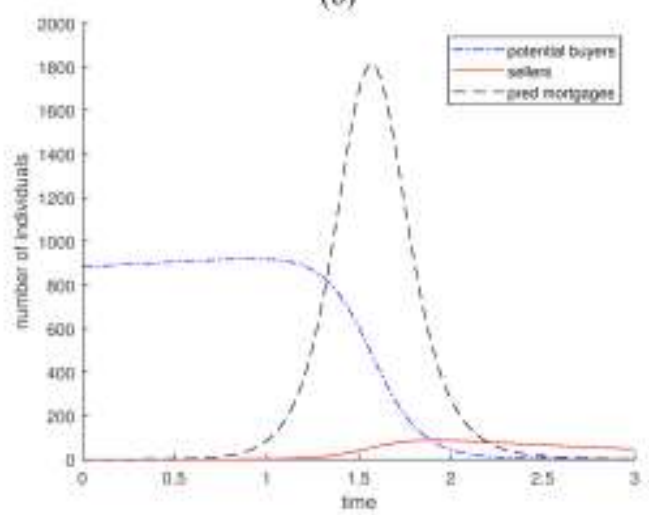

(c)

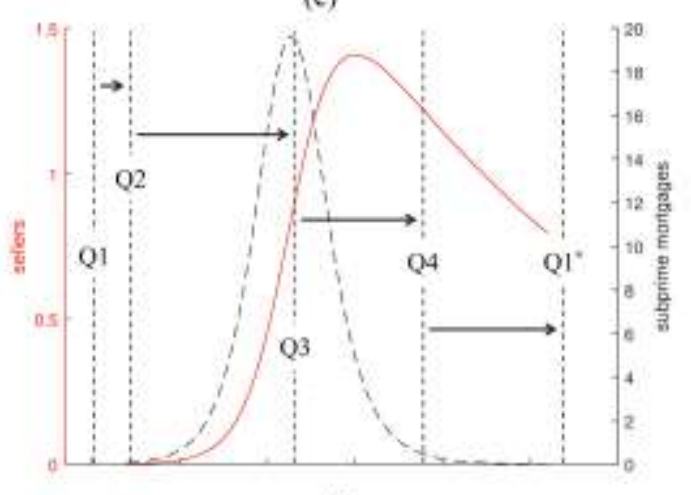

nome

Notes: Supply (demand) curves express the relationship between sellers (buyers) of subprime mortgages and the number of sold subprime mortgages (government regulations). In (b, c), line style and color indicate the number of potential buyers (blue, dot-dashed), sellers of subprime mortgages (red, solid), and the number of sold subprime mortgages (black, dashed). In (c), as the true number of potential buyers of mortgages are unknown, we focus on the number of sellers of subprime mortgages and number of subprime mortgages sold. In order to readily compare to empirical data, the results in (c) are scaled from those in (b). The boundary of each quadrant of the wheel of misfortune is indicated by the vertical dotted lines; movement from one quadrant to another is illustrated by arrows. 
(a)

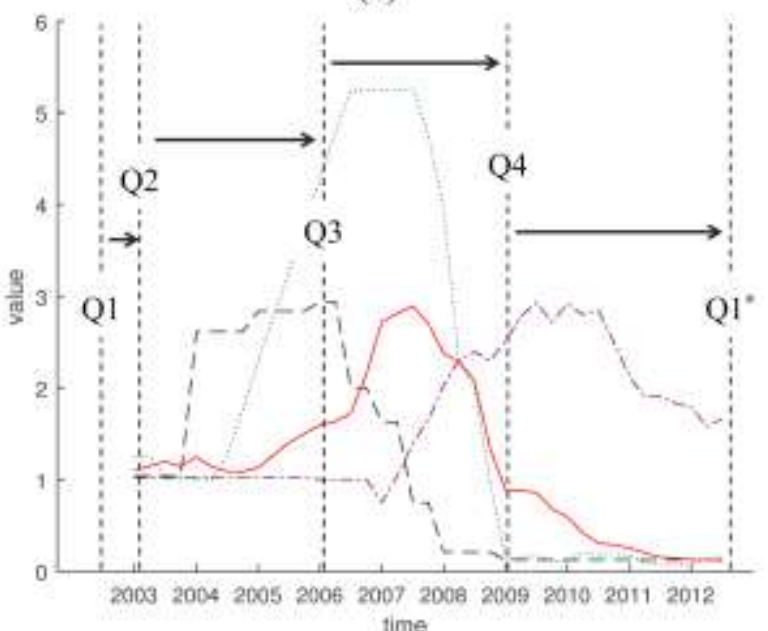

(b)

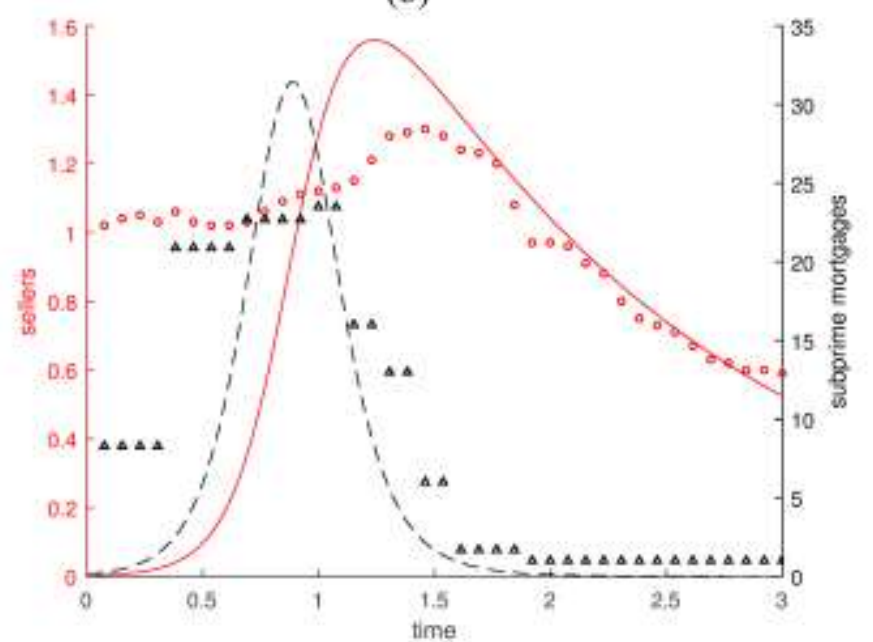

Notes: In (a) line style and color indicate market data: sellers of subprime mortgages (red, solid), number of sold predatory mortgages (black, dashed), number of home foreclosures (purple, dot-dashed), and federal interest rates (green, dotted). Note that the market data has been transformed to improve readability (see the main text for details). The four quadrants of the wheel of misfortune are indicated by vertical lines; movement from one quadrant to another are illustrated by arrows. In (b) lines represent the output from a basic Lotka-Volterra model, overlaid by markers showing the un-transformed market data. Color and style indicate the variable: sellers of subprime mortgages (red, solid; circles) and the number of sold predatory mortgages (black, dashed; triangles). Note that the model output has been scaled to correspond to the data. Framework parameters are $r=0.05, \alpha=0.07, \beta=0.129$, and $v=0.689$. Initial conditions are 894.52 (prey, potential buyers) and 0.0131 (predators, sellers). For details on the calibration of the Lotka-Volterra model, see Appendix A. 
(a)

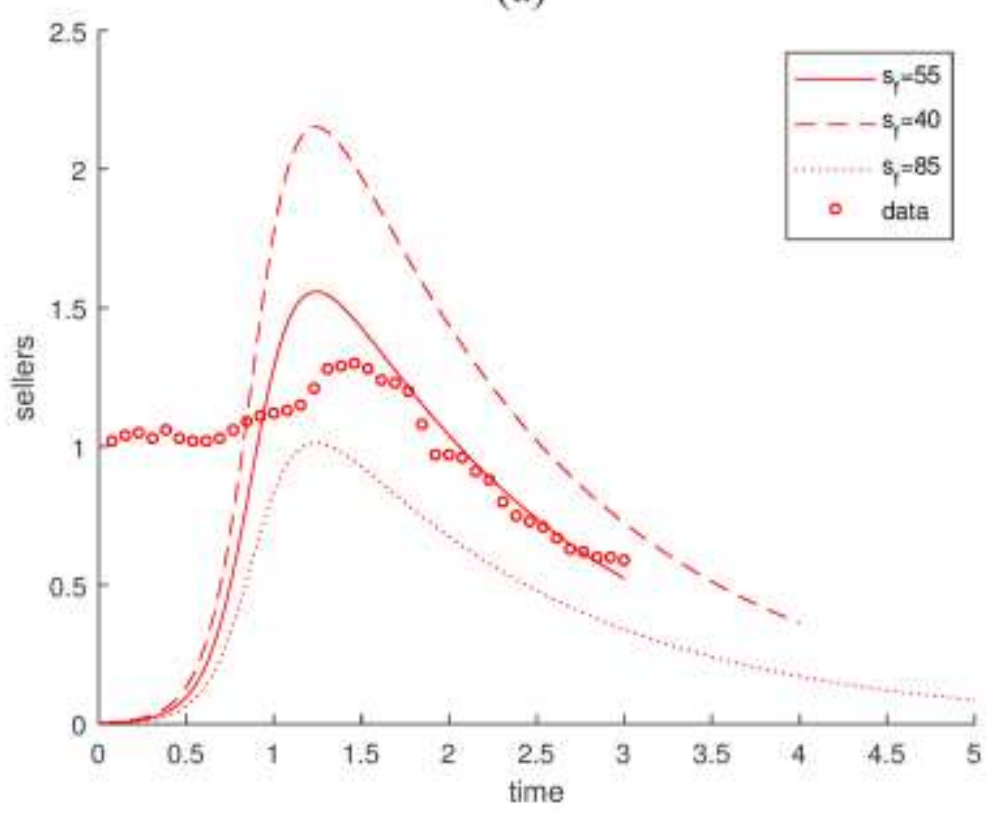

(b)

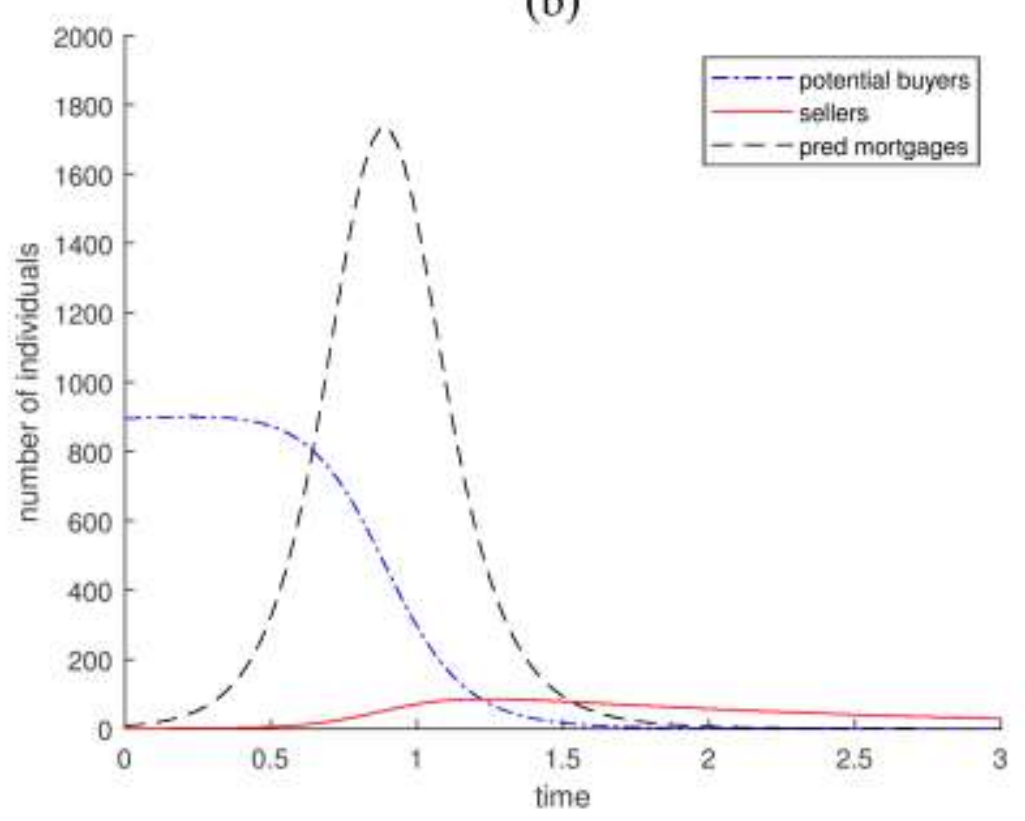

Notes: In (a) market data are given by open circles, while simulation results are smooth curves or lines. Line style indicates a combination of scaling factors $\left(s_{f}\right)$ and timescales of the simulation: $s_{f}=55$ and timescale of 3 time steps (solid), $s_{f}=40$ and timescale of 4 time steps (dashed), and $s_{f}=85$ and timescale of 5 time steps (dotted). For the sake of readability, we focus on the number of sellers of subprime mortgages. For comparison, panel (b) illustrates un-scaled simulation results for all market agents. Color and style indicate the variable: sellers of subprime mortgages (red, solid), the number of sold predatory mortgages (black, dashed), and the number of potential buyers (blue, dot-dashed). 
(a)

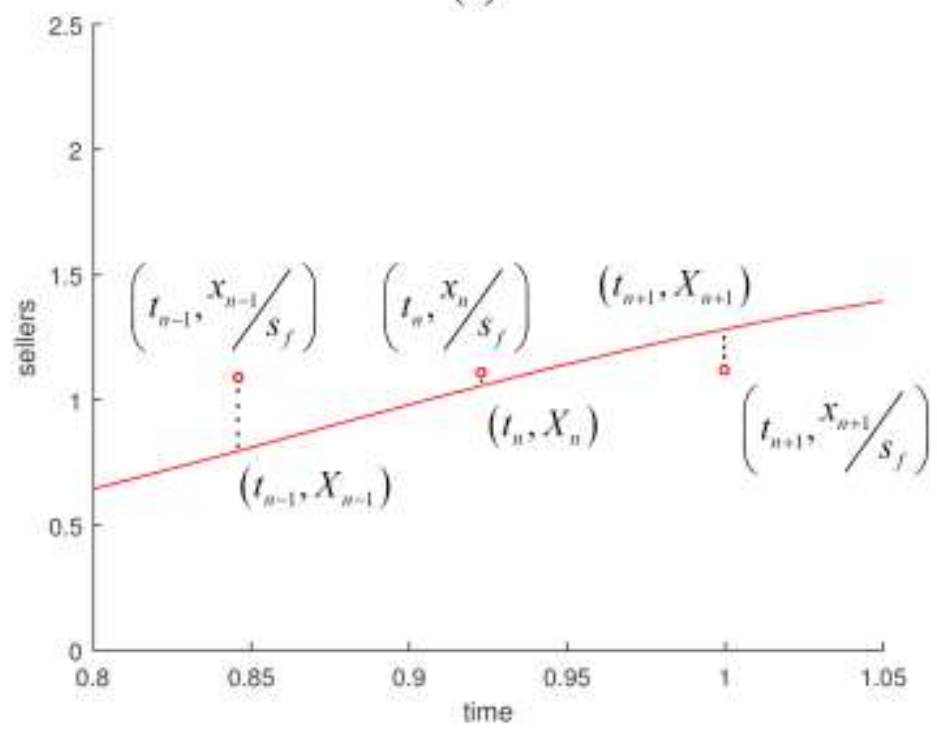

(b)

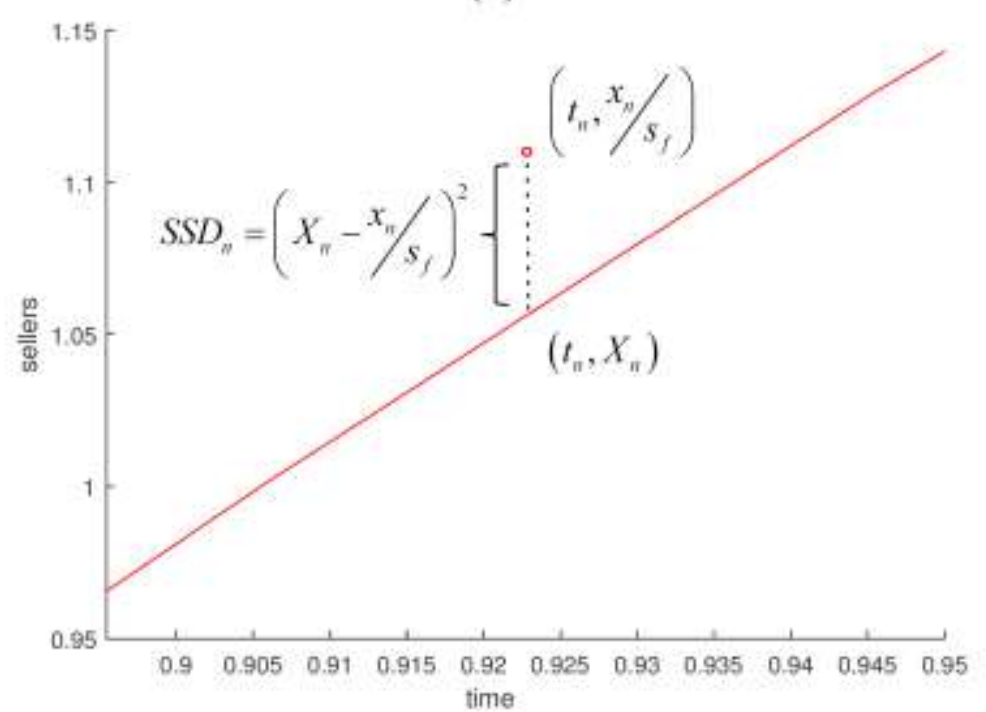

Notes: Data (open circles) and theoretical model results (solid lines) depict a subset (zoomed-in view) of the data/simulation in Figure S1. For the sake of visibility, we focus on the number of sellers of predatory mortgages. In (a) and (b), we have added dotted lines to show the error between the data and the simulation results, and $(x, y)$ coordinates for each point in the data and its corresponding point in the theoretical model output. The symbol and subscript $t_{n}$ represents the time at observation $n, X_{n}$ is the number of sellers in the data at observation $n, x_{n}$ is the corresponding quantity of sellers from the simulation at observation $n$, and $s_{f}$ is the scaling factor. 